\title{
Control of pink discoloration in coconut water
}

\author{
B. Garcia ${ }^{1}$, D. B. Masa ${ }^{2}$, M.J. Rodriguez ${ }^{3}$ and R. Rolle ${ }^{4}$
}

\begin{abstract}
The pink discoloration in coconut water is a result of the initial enzymatic action of polyphenol oxidase (PPO) on the phenolic substrates which are naturally present in the product. Activity of the enzyme is further enhanced by metal contamination such as copper and exposure of the product to high temperature during its processing and storage.

The optimum copper concentration to initiate pinking in coconut water was established at $3.96 \times 10^{-}$ ${ }^{04} \mathrm{mM}$. The PPO level was also shown to vary among coconut varieties and ages. When subjected to optimum conditions for enzymatic activity, the water from younger nuts (7-8 months old) went pink while mature nuts (9-10 months old) showed no discoloration. Application of food-grade resins to remove the phenolic substrates in coconut water was deemed as a possible solution to prevent the discoloration. Further testing in this area needs to be done.
\end{abstract}

Key words: Coconut water, Discoloration, Polyphenol oxidase.

1 Science Research Specialist, Product Development Department, Philippine Coconut Authority, Diliman, Quezon City, Philippines

2 Department Manager II, Product Development Department, Philippine Coconut Authority, Diliman, Quezon City, Philippines, dina_masa04@yahoo.com

3 Division Chief III, Virology-Biochemistry Division, Albay Research Center, Philippine Coconut Authority, Guinobatan, Albay, Philippines

4 Agricultural and Food Engineering Technologies Service, Food and Agriculture Organization 


\section{Introduction}

Nowadays, Ready-To-Drink (RTD) juices dominate the beverage market. People tend to favor natural drinks, thus the increasing popularity of buko (young coconut) water, usually served in plastic cups with covers or in polyethylene (PET) bottles, and with or without coconut meat. It has a delicate sweet flavor and is typically served chilled for drinking, with or without sugar.

Coconut water is naturally sterile, contains vitamins and minerals and is relatively high in potassium and low in sodium salts (Banzon et al., 1990). Coconut water also contains dilute amounts of nutrients particularly proteins, fats and sugars. Due to this nutrient content, it is very susceptible to the growth of microorganisms (Pamintuan, 2002). It easily ferments once exposed to air when the liquid rapidly loses most of its nutrients and its organoleptic properties. Most commercial producers of coconut water drinks employ a high-temperature/short-time pasteurization process to preserve sterility. But thermal processing has a drawback - it eliminates not only the risk of bacteria, but also some of coconut water's nutrients and almost all of its delicate flavor (http://www. fao.org/ag/magazine/9810/spot3.htm).

The FAO has taken out a patent on a new process that would allow manufacturers to bottle coconut water that is biologically pure, very tasty and full of the salts, sugars and vitamins without undergoing the thermal process. Morton Satin, Chief of FAO's Agricultural Industries and Postharvest Management Service (AGSI), invented the new cold sterilization process which involves the application of microfiltration technology water is filtered through a medium (porcelain or polyacrylic gel) - that retains all microorganisms and spores and renders the permeate commercially sterile. Coconut water produced from this process turned out not so different from fresh coconut water except for some discoloration - referred to as "pinking".

Pinking of the coconut water during processing and storage is primarily due to the presence of naturally occurring phenolic substrates in the coconut water. These phenolic substrates are acted on by the enzyme polyphenol oxidase (PPO), also naturally present in the coconut water, which activity is enhanced by exposure to higher temperatures and metal contamination. To control the pink discoloration of coconut water, the application of secondary direct food additives to remove the phenolic substrates may be considered. Because of the natural/organic image of coconut water and known health risk concerns associated with the use of chemical additives in food products, the application of chemical reagents is not a highly recommended option for use in coconut water processing. Treatment of coconut water with food-grade resins, on the other hand, is designed to adsorb polyphenolic constituents in beverages which are then removed by filtration and therefore is not considered as an additive.

This study aims to prevent the pink discoloration of coconut water through treatment of food-grade resins. The specific objectives of this study were: 1) to determine the optimum copper concentration that initiates pinking in coconut water; 2) to determine the relative enzyme activities of coconuts of different varieties and ages that are utilized for coconut water drink; 3) to determine suitable food-grade resin/s for use in coconut water; and 4) to establish a recommended dosage for use in coconut water drink processing.

\section{Materials and methods}

A. Reagents and Materials. Copper sulphate pentahydrate, glacial acetic acid and sodium acetate were of analytical grade. Food-grade PVPP (single-use Divergan $\mathrm{S}^{\circledR}$ ) was obtained from BASF-Philippines, through San Miguel Corporation. Dosage rates for PVPP are expressed as grams per hectoliter in accordance with brewing industry practice. Food-grade calcium bentonite was obtained from Aspen Commercial Corporation, Katipunan Ave., Quezon City, Metro Manila and gelatin powder (USP) from Alysons' Chemical Enterprises, Araneta Ave., Quezon City, Metro Manila. Different varieties of coconuts of different ages 
(7, 8, 9 and 10 months) were freshly harvested from the Albay Research Center (ARC) Farm, Guinobatan, Albay.

B. Instrumentation. WTW Meter $\mathrm{pH} 330 /$ Set I was used for the measurement of the $\mathrm{pH}$ of coconut water and other $\mathrm{pH}$ adjustments required for the experimentation. Beckman $\mathrm{DU}^{\circledR}$ Series 500 UV/Vis spectrophotometer, Single Cell Module with Standard Cell Holder, was used for the measurement of the DOPA-quinone (pink) formation in coconut water. Detection wavelength was set at $470 \mathrm{~nm}$. Memmert BE Model 300 incubator was used for the incubation of samples at $34^{\circ} \mathrm{C}$.

\section{Measurement of Polyphenol Oxidase Activity}

a. Sample preparation. The young coconut fruit was washed thoroughly to remove dirt, soil or any debris adhering to the husk and was air-dried. The husk and immature shell were chopped off to expose the tender meat. The meat was gently pierced to release the coconut water which was filtered through cheesecloth and collected in a clean container. Coconut water from three nuts of the same variety and age was mixed to facilitate sampling. The $\mathrm{pH}$ of the coconut water was measured and recorded. The test volume of coconut water was transferred in an Erlenmeyer flask and labeled appropriately.

\section{b. Measurement of polyphenol oxidase activity.} Reagents used were $0.1 \mathrm{M}$ stock acetate buffer solution prepared with the same $\mathrm{pH}$ as the coconut water and $10 \mathrm{mM}$ stock $\mathrm{CuSO}_{4}$ in buffer. A pre-determined amount of copper solution (in buffer) and acetate buffer were added to the coconut water. The contents were mixed thoroughly by swirling the flask several times. Initial enzyme activity was measured by taking an aliquot from the sample and reading its absorption at a wavelength setting of $470 \mathrm{~nm}$. Samples were then incubated at $34^{\circ} \mathrm{C}$. Subsequent measurements were taken at 60 minute intervals until a reaction period of 6 hours was completed.

\section{Effect of Treatment with Food-Grade Resin}

a. Food-grade resin preparation. Prior to use, slurries were prepared as follows:

Polyvinylpolypyrrolidone (PVPP-single-use Divergan $\mathbf{S}^{\circledR}$ ). A measured amount, as recommended by the makers of the PVPP powder, was directly added to the coconut water and mixed for a minimum of 60 minutes to ensure swelling.

Calcium bentonite. Following a bentonite-towater ratio of $5-6 \% \mathrm{wt} / \mathrm{vol}$, calcium bentonite powder was slowly added to hot water and left to stand for 48 hours.

Gelatin. Dry gelatin was hydrated in warm water at $60 \mathrm{~g} / \mathrm{L}(6 \%)$ and the slurry left to stand for 18 hours at $10^{\circ} \mathrm{C}$.

b. Measurement of the effect of treatment with food-grade resin. Food-grade bentonite, gelatin and single-use PVPP were tested for effectiveness in preventing the pink discoloration in coconut water. The coconut water was added with various amount of foodgrade resin and pre-incubated for a certain period of time. The effectiveness of these resins was tested based on the amount of resin to be added, method of slurry preparation, mode of mixing, contact temperature and contact time. At the end of each contact time, the sample was filtered using a Whatman No.4 filter paper. The pre-determined amount of copper solution (in acetate buffer) was then added to the sample. Initial enzyme activity was measured by taking an aliquot from the sample and reading its absorption at a wavelength setting of $470 \mathrm{~nm}$. Samples were then placed in the incubator with temperature set at $34{ }^{\circ} \mathrm{C}$. Subsequent measurements were taken at 60 minute intervals for a period of 6 hours.

\section{Results and discussion}

The study is divided into two main activities. The first is the measurement of the polyphenol oxidase activity in coconut water and the other is the determination of the effect 
of treatment with food-grade resin in preventing the pink coloration in coconut water.

\section{A. Measurement of Polyphenol Oxidase Activity}

The pink coloration of coconut water during processing and storage is a product of an initial enzymatic oxidation of naturally occurring phenolic substrates in the coconut water. This enzymatic action is mainly associated with polyphenol oxidases, which are able to act on tyrosine, a monophenol in coconut water, in the presence of oxygen. On farms, the collected coconut water is often exposed to air and is not stored properly, mainly because of the lack of appropriate storage facilities and materials at hand and unawareness of farmers to the chemical changes undergone by the coconut water. Furthermore, during the collection of the water, metal contaminants are unknowingly introduced by means of the 'bolos'/knives used in opening the nuts and metal containers used to contain the water. The presence of metal ions such as copper enhances the pinking of coconut water which is also dependent on $\mathrm{pH}$ and the presence of complexing agents (Wong, 1995).

To stimulate the pinking reaction that occurs in coconut water, an amount of copper solution was introduced into the reacting system. Copper enhances the pink coloration of coconut water enabling complete visual observation and mechanical measurement of the color change within laboratory hours. The optimum copper concentration that would initiate pinking in coconut water was determined experimentally. Nuts were harvested early in the morning and samples were prepared and measured for polyphenol oxidase activity as shown in Figure 10. Sampling was done in an air-conditioned room since a lower temperature will delay most biological reactions. The tests were carried out using coconuts in the age range of seven to ten months since these are the ages commonly utilized for drinking. Several coconut varieties were included in a preliminary study to determine which has the highest enzyme activity, simultaneously determining the copper concentration and reaction temperature. A mixture of 7- to 10-month old nuts were tested from indigenous coconut varieties in the Philippines such as Aromatic Green Dwarf, Pilipog Green Dwarf, Tacunan Green Dwarf, Coconiño (Green Dwarf) and Laguna Tall and varieties common in the Asia Pacific region such as the Malayan Red Dwarf and Malayan Yellow Dwarf (Figure 11).

Results indicate the highest polyphenol oxidase activity for the Aromatic variety and the lowest for the Tacunan Green Dwarf, as shown in Figure 12. The initial copper concentration was established at $0.005 \mathrm{mM}$, based on its effect in hastening pinking of the water, and the reaction temperature at $34{ }^{\circ} \mathrm{C}$.

Testing the enzymatic activity for the different ages (7-10 month-old nuts) of the Aromatic variety showed a maximum at 7 months in age as illustrated by its high percentage of absorbance (Figure 13) and pinking of the water at hour 3 of the reaction period. No pinking was observed from 9- and 10-month old nuts. A review of literature evinced that generally, younger fruits manifest higher enzyme activity compared to mature ones. Further determinations on the enzymatic activity of different ages of coconut were

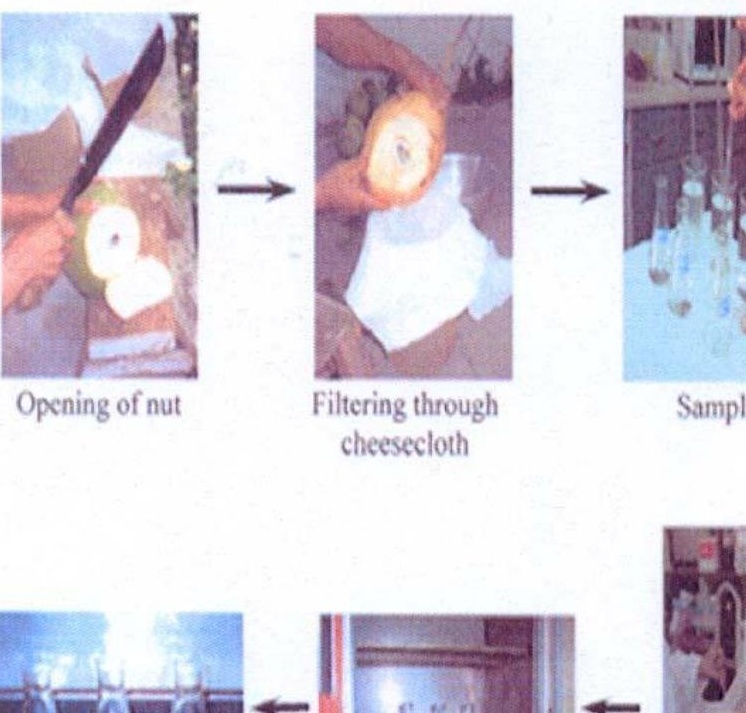


Figure 10. Measurement of polyphenoloxidase activity

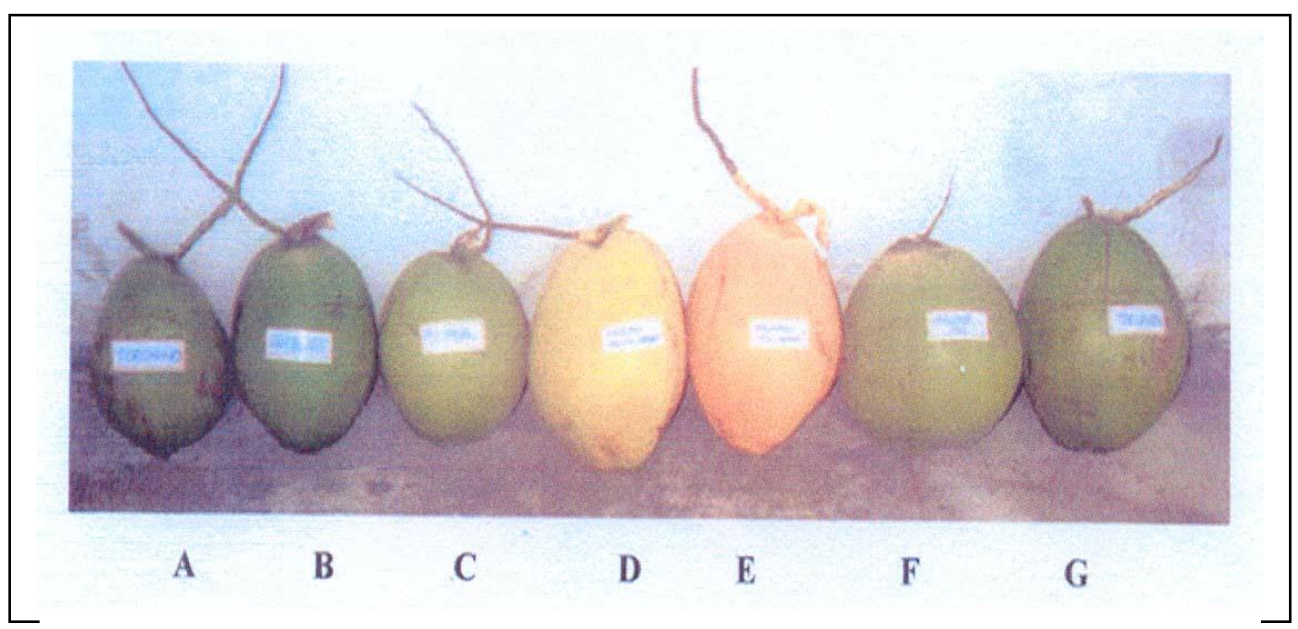

Figure 11. Different varieties of coconuts in the Philippines: ACoconiño (Green Dwarf), B- Aromatic Green Dwarf, C-Pilipog Green Dwarf, D-Malayan Yellow Dwarf, E-Malayan Red Dwarf, F-Laguna Tall and G-Tacunan Green Dwarf

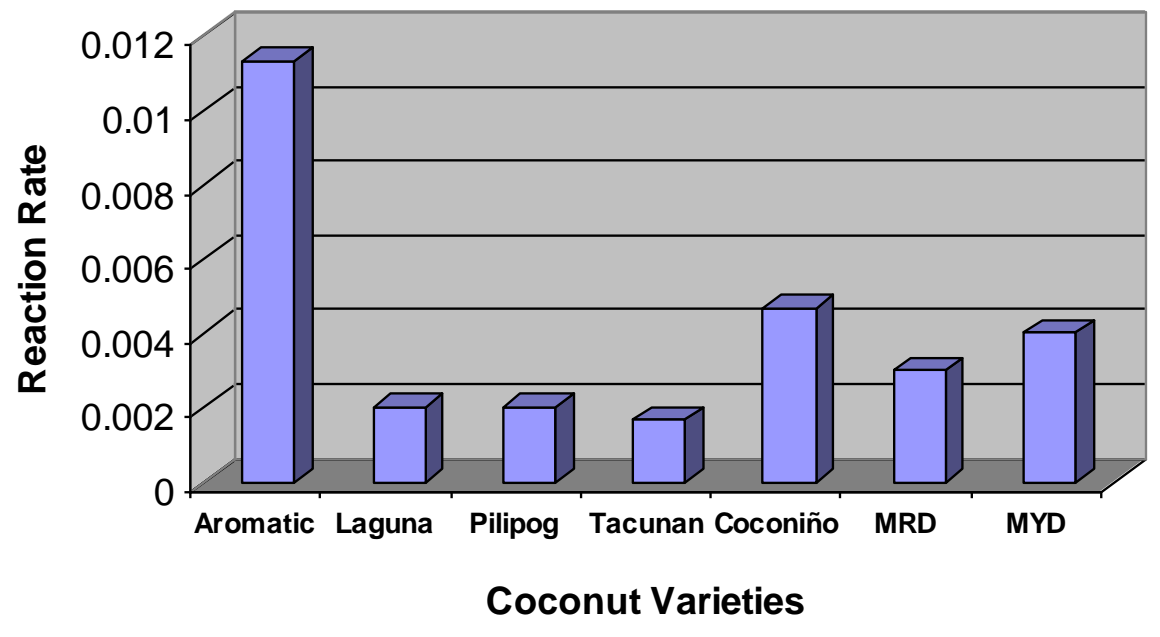


Figure 12. Polyphenoloxidase activity of the different varieties of coconut in the Philippines

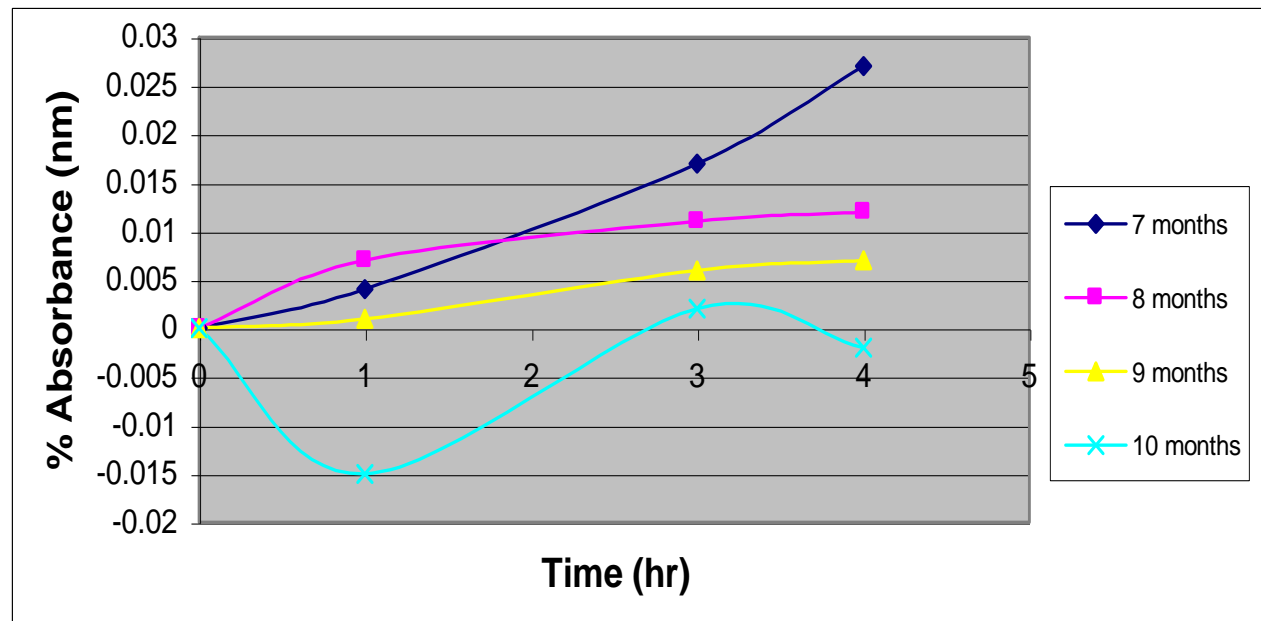

Figure 13. \% Absorbance of coconut water at different stages of maturity vs. time undertaken and are discussed in the following sections. For the determination of the optimum copper concentration, 7-month old Aromatic variety coconuts were used. tried, starting from $0.005 \mathrm{mM}$, until a close range of concentrations was obtained that initiated pinking in the coconut water of the 7month old Aromatic variety. Test parameters, working conditions and treatments were as follows:

\section{Parameters:}

Coconut Variety/Age: Aromatic Coconut/ 7month old

pH of Coconut Water: 5.00

$0.91 \mathrm{mM}$ and $0.099 \mathrm{mM} \mathrm{CuSO}_{4}$ solution prepared using acetate buffer with the same $\mathrm{pH}$ as the coconut water (serial dilution)

\section{Working Conditions:}

Copper ng in 
Samples were prepared in an air conditioned room at a temperature of $26-27^{\circ} \mathrm{C}$

Wavelength setting: $470 \mathrm{~nm}$

Reaction Temperature: $34{ }^{\circ} \mathrm{C}$ (incubator)

Treatments: (coconut water + copper sulphate + buffer)

\begin{tabular}{|l|l|l|l|l|l|}
\hline $\begin{array}{c}\text { Amount of } \\
\text { Coconut } \\
\text { Water } \\
(\mathbf{m l})\end{array}$ & $\begin{array}{c}\text { Amount of 0.91 } \\
\text { mM CuSO4 in } \\
\text { Buffer }(\mathbf{m l})\end{array}$ & $\begin{array}{c}\text { Amount of } \\
\mathbf{0 . 0 9 9} \mathbf{~ m M} \\
\mathbf{C u S O} \mathbf{~}_{\mathbf{~ i n}} \\
\text { Buffer }(\mathbf{m l})\end{array}$ & $\begin{array}{c}\text { Amount } \\
\text { of Buffer } \\
(\mathbf{m l})\end{array}$ & $\begin{array}{c}\text { Total } \\
\text { Volume } \\
(\mathbf{m l})\end{array}$ & $\begin{array}{c}\text { Total Copper } \\
\text { Concentration } \\
\text { in Solution } \\
(\mathbf{m M})\end{array}$ \\
\hline 27 & 0.12 & 0 & 2.88 & 30 & 0.00364 \\
\hline 27 & 0 & 0.51 & 2.49 & 30 & 0.00167 \\
\hline 27 & 0 & 0.30 & 2.70 & 30 & 0.00099 \\
\hline 27 & 0.030 & 0 & 2.97 & 30 & 0.00091 \\
\hline 27 & 0 & 0.21 & 2.79 & 30 & 0.000693 \\
\hline 27 & 0.015 & 0 & 2.985 & 30 & 0.000455 \\
\hline 27 & 0 & 0.12 & 2.88 & 30 & 0.000396 \\
\hline 27 & 0 & 0.076 & 2.924 & 30 & 0.000250 \\
\hline 27 & 0 & 0.038 & 2.962 & 30 & 0.000125 \\
\hline 27 & 0 & 0.030 & 2.97 & 30 & 0.000099 \\
\hline 27 & 0 & 0 & 3.0 & 30 & 0 \\
\hline
\end{tabular}

Three replicates were made and all were subjected to the same parameters (except for the $\mathrm{pH}$ of the coconut water), working conditions and treatments. Two of the replicates showed similar results in terms of the optimum copper concentration. An average of the replicates was made and the calculated rate of reaction (Table 4) revealed that the optimum copper concentration was $3.96 \times 10^{-4} \mathrm{mM}$ as shown in Figure 20 . Pinking was observed to occur at hour 3 of the reaction period at this level of copper concentration.

Pinking of the coconut water will proceed naturally, even without the addition of copper, when the optimum conditions for the reaction are reached. However, PPO is a copper containing enzyme and any mechanism of action for PPOs includes the role of copper (Whitaker, 1994). The copper component of the enzyme is reduced by reaction with the phenolic substrates. Addition of copper either amplifies the binding of the oxyDPO moiety or acts as an ion activator at a certain concentration thereby speeding up the hydroxylation of the monophenol or oxidation of the diphenol (reference - Whitaker?).
Table 4. Rate of reaction of the different copper concentration

\begin{tabular}{|l|l|}
\hline Copper Concentration & Reaction Rate \\
\hline 0 & $-5.55556 \mathrm{E}-06$ \\
\hline 0.000099 & $1.33333 \mathrm{E}-05$ \\
\hline 0.000125 & $8.11111 \mathrm{E}-05$ \\
\hline 0.00025 & 0.000143333 \\
\hline 0.000396 & 0.000182222 \\
\hline 0.000455 & 0.00016 \\
\hline 0.000693 & 0.000176667 \\
\hline 0.00091 & 0.000134444 \\
\hline 0.00099 & 0.000143333 \\
\hline 0.00167 & 0.000133333 \\
\hline 0.00364 & 0.000128889 \\
\hline
\end{tabular}

The Aromatic coconut variety is indigenous to the Bicol Region alone, which is located at the south of Luzon Island in the Philippines. Although sought after for its very tasty water and meat, the nut is quite small and is not as commonly utilized for coconut water processing as the Laguna Tall variety, which is 
distributed throughout the country and contains a larger volume of water. Adapting to the Philippine situation of varietal preference for young coconut water utilization, the study focused on the 7-month old Laguna Tall coconut. The optimum copper concentration established for the Aromatic variety were applied to the Laguna Tall and the results were almost the same. Thus, further testing of the PPO level of the different ages of coconut was conducted using the Laguna Tall variety.

\section{Determination of the Polyphenol Oxidase Level in Different Ages of Coconut}

In the Philippines, the tall varieties are more widely distributed and commercialized. Any young coconut water drink is often of the Laguna Tall variety since it is the most generally utilized because of the large volume of its water which averages from 400-600 milliliters (ml). It is usually the 7 to 10 month-old nuts that are used for the production of young coconut water drink. However, taken fresh and singly, it is the 9month old nut that is deemed the optimum age because of its sweeter water and slightly thicker coconut meat that is still tender. It is also a common practice in the country to mix the coconut water from these four ages. Pinking is not often encountered in mixtures, particularly when pasteurized. However, it is not a rare occurrence.

To determine the polyphenol oxidase level of the different ages of coconut water of the Laguna Tall variety, the previously established optimum copper concentration was applied to 7, 8- and 9-month old nuts. All replicates displayed a general trend that the 7-month old nut had the highest absorbance readings as shown in Figure 15 below and the highest calculated reaction rate (Table 5). Pinking was observed to occur at hours 3-4 of the reaction period. Pinking was not observed for the 9month old nut.

Using the generalization that younger fruits posses higher enzyme level as a factual basis, further testing of the enzyme activity of the different ages of Laguna Tall coconut were undertaken. Coconut water of nuts ranging from 3-10-months old was treated with copper. Three replicates were made and results revealed that the 7-month old nut still has the highest enzyme level as shown in the plot of calculated reaction rate (Figure 16) followed by the 8-month old and the 10-month old nut the least. The 6month old nut showed high
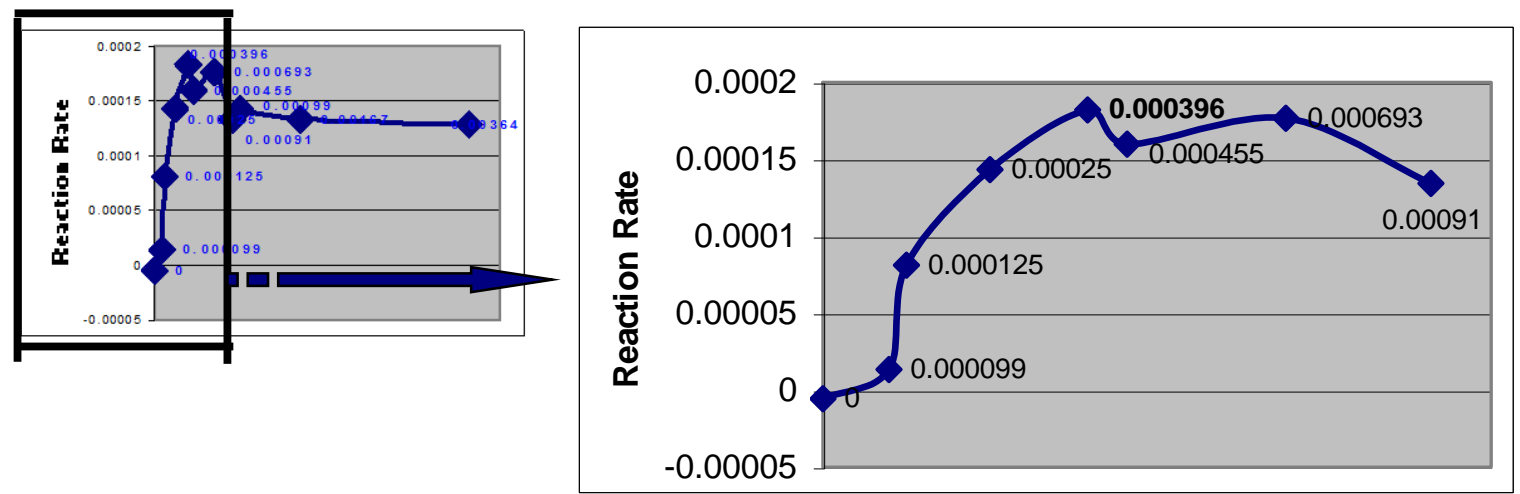

Figure 14. Rate of reaction of the different copper concentrations

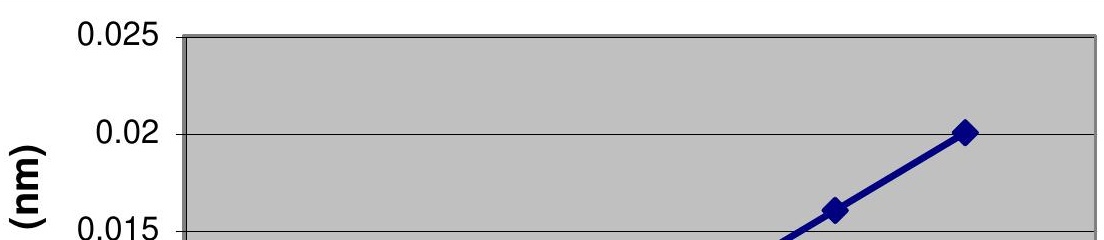


Figure 15. \% Absorbance of different ages of coconut water vs. time

Table 5. Rate of reaction of the different ages of coconut

\begin{tabular}{|c|c|c|c|}
\hline \multirow[b]{3}{*}{ Time (hr) } & \multicolumn{3}{|l|}{ Age of Coconut } \\
\hline & 7 Months & 8 Months & 9 Months \\
\hline & Reaction Rate & & \\
\hline 1 & 0.002 & 0.001 & 0.001 \\
\hline 2 & 0 & -0.001 & -0.001 \\
\hline 3 & 0.006 & 0.005 & 0 \\
\hline 4 & 0.004 & -0.002 & 0 \\
\hline 5 & 0.004 & 0.002 & 0 \\
\hline 6 & 0.004 & 0 & 0.002 \\
\hline Average & 0.003333 & 0.000833 & 0.000333 \\
\hline
\end{tabular}

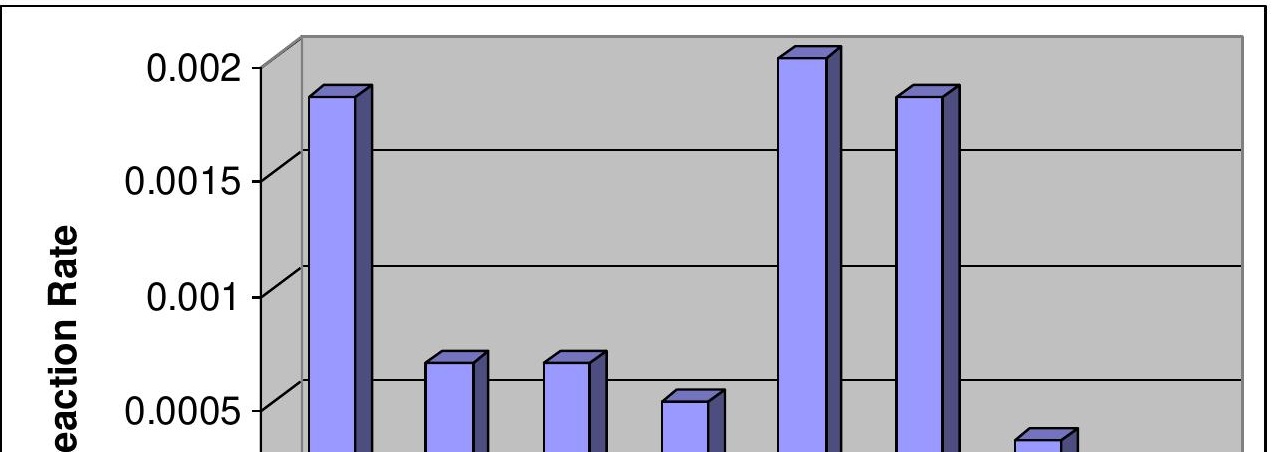


Cord 2007, 23 (2)

Figure 16. Reaction rate of the different ages of coconut

activity, however, this age is not considered for coconut water utilization because of its unpalatable taste. The 9-month old nut did not show pinking in any of the replicates.

Pinking of the coconut water is influenced by several factors such as the amount of phenols and enzyme present, temperature, $\mathrm{pH}$, ions and ionic strength, presence of inhibitors/activators and availability of oxygen.

The composition of coconut water changes markedly as the nut matures. These changes may be roughly divided into three stages. First, there is an accumulation of reducing sugars, fructose and glucose and amino acids while the meat is still absent. Second, there is loss of water from the coconut, but its total weight increases, sucrose appears in the water, the specific gravity increases and meat starts to form. Third, the specific gravity of the water falls and there is a sudden rise in the oil content of the meat (endosperm) (Sison, 1984). The age range of the coconuts in the first stage is from 3-6 month old. Meat starts to appear in the 7-month old coconuts and gradually thickens as the nuts mature. The second stage thus pertains to the 79 month coconuts. The last stage, starting from the 9-month coconuts, lasts up to the time when they are harvested for copra production. Accompanying these major changes are probable changes in the water's phenolic contents. There is an increase in protein content as the nut matures, thus also in the proportion of the tyrosine, a monophenol, which is a major substrate for the coconut water PPO. Some phenolic compounds do not serve as substrates of enzymatic browning reactions but may act as synergists or inhibitors of PPO from certain sources (Shahidi and Naczk, 1995).

Aside from tyrosine, other phenolic compounds that are responsible for the aroma and taste may also be changing in proportion. Monophenols and o-diphenols have been considered as the exclusive substrates of tyrosinase for a long time. In a recent study, the reaction of tyrosinase was studied with two new classes of substrates: aromatic amines and oaminophenols, structural analogues of monophenols and o-diphenols respectively. They were found to undergo the same catalytic 
reactions (ortho hydroxylation and oxidation), as documented by product analysis and kinetic studies (Lerch and Ettlinger, 1972).

Temperature and $\mathrm{pH}$ affect both the stability and activity of the enzyme. The optimum temperature rangee for the coconut water PPO was established at $34-35{ }^{\circ} \mathrm{C}$. These temperatures are often encountered when large volumes of coconut water are pasteurized and the target temperature is slowly reached and also when the drinks are not properly stored during transport and sale. The optimum $\mathrm{pH}$ for the Laguna Tall variety was established at 4.8-5.10, the range for the 7-month old nut. Sensitivity of the PPO to the $\mathrm{pH}$ was more varied, as exemplified by the pinking of the 7-month old Aromatic coconut variety at higher $\mathrm{pH}$. Adjustment of $\mathrm{pH}$ to an optimum, by the use of a buffer, does not enhance enzyme activity.

Some workers have reported inhibitory factors that develop in the water and solid endosperm as the fruit matures that function in initiating and maintaining the dormancy of the embryo (Sison, 1984). These inhibitory factors may affect the enzyme activity of the mature nuts as exemplified by pinking of the 7- and 8-month but not of the 9-and 10-month old nuts.

To further confirm that the 7-month old nut is the main contributor of pinking in a coconut water mixture, different proportions of 7-, 8-, and 9-month old coconut water were tested for enzymatic activity. Replicates of this test (done in triplicates) made it clear that the set containing the highest proportion of 7-month old nut had the highest absorbance reading but, when mixed with larger volumes of 9-month old nut water, does not show pinking.

Mixing the coconut water from the different ages provides various proportions of the enzyme and substrate. It is expected that at higher proportion of water from the 7-month old nut more enzyme will be present and that products formed will be in relative amount to the enzyme. However, when the proportion of the 9-month old nut was increased, no pinking was observed although water from the younger nuts was present. Although substrates are abundant, oxidation of substrate stops long before all the substrate has been converted to product. The reaction comes to stop because of inactivation of the enzyme and not because of exhaustion of substrate. The cause of this inactivation of enzyme is not a result of instability of enzyme to the $\mathrm{pH}$ or temperature used. Rather, inactivation is due to reaction of the product, obenzoquinone, with the enzyme to form a covalent linkage in or near the active site (Whitaker, 1972). Since no pinking was observed, it may be assumed that either the enzyme is not activated by a change in $\mathrm{pH}$ or that it is affected by the inhibitory component in water from mature coconuts.

\section{B. Effect of Treatment with Food-Grade Resin}

By employing the cold pasteurization process, the enzyme present in coconut water is not inhibited and is therefore free to react with the phenolic substrates. Thus, taking out these phenolic substrates in the reaction system may solve the problem of pinking. Removal of these substrates is made possible through use of foodgrade resins, which are specific for this type of action. Use of food-grade resins is an age-old practice in the wine and beer industry. Moreover, these resins are now also finding application in different beverages, such as juices, to remove haze/discolorations formed during processing and storage. However, the effectiveness of these food-grade resins depends on several factors such as the type of agent and its compatibility to the beverage treated, method of preparation and addition, concentration, wine or juice $\mathrm{pH}$, metal content, contact temperature and time, age, and previous treatments.

Food-grade resins tested for this study includes single-use polyvinylpolypyrrolidone (PVPP), calcium bentonite and gelatin. Treatments were applied to 7-month old nuts of the Laguna Tall coconut variety employing established optimum conditions. Recommended dosage levels were tried for all types of resins used. 


\section{Polyvinylpolypyrrolidone (PVPP), single- use}

Several test trials were done on the application of single-use PVPP (Divergan $S \square$ ) in coconut water. Each trial run was focused on one factor that affects the resin's effectiveness as a phenol-removing substance.

First to be considered was the amount to be added to the water. PVPP can be added directly to the water thus, avoiding the inconvenience of having to prepare a slurry in advance and let it stand, in order to increase its adsorbing capacity. Dosage rates used started from the least amount and increased gradually as trials were made. Test parameters, working conditions and treatments were as follows:

Parameters:
Coconut Variety/Age: Laguna Tall, 7-month old

$\mathrm{pH}$ of Coconut Water: 4.68

$0.1 \mathrm{mM} \mathrm{CuSO}$ solution prepared using acetate buffer with the same $\mathrm{pH}$ as the coconut water

Working Conditions:

Preparation of samples done in an air conditioned room with a temperature of 27$28^{\circ} \mathrm{C}$

Amount of Resin: 10 and $20 \mathrm{mg}$

Mixing Temperature/Time: 30 minutes, $28^{\circ} \mathrm{C}$ (magnetic stirring, mixing set at medium speed)

Pre-incubation Temperature/Time: $34^{\circ} \mathrm{C}, 2$ and 4 hours

Buffer and copper solution added after the preincubation period.

Reaction Temperature/Time: $34^{\circ} \mathrm{C}, 6$ hours

Wavelength setting: $470 \mathrm{~nm}$

Treatments: (coconut water + copper sulphate + buffer)

\begin{tabular}{|l|l|l|l|l|l|}
\hline Sample & $\begin{array}{l}\text { Amount of } \\
\text { Coconut } \\
\text { Water }(\mathbf{m l})\end{array}$ & $\begin{array}{l}\text { Amount of } \\
\mathbf{0 . 1} \mathbf{~ m M} \\
\mathbf{C u S O} \text { in } \\
\text { Buffer }(\mathbf{m l})\end{array}$ & $\begin{array}{l}\text { Amount of } \\
\text { Buffer } \\
(\mathbf{m l})\end{array}$ & $\begin{array}{l}\text { Total } \\
\text { Volume } \\
(\mathbf{m l})\end{array}$ & $\begin{array}{l}\text { Total Copper } \\
\text { Concentration in } \\
\text { Solution }(\mathbf{m M})\end{array}$ \\
\hline $\begin{array}{l}\text { A (2 hrs pre- } \\
\text { incubation) }\end{array}$ & 90 & 0.396 & 9.604 & 100 & 0.000396 \\
\hline $\begin{array}{l}\text { B (4 hrs pre- } \\
\text { incubation) }\end{array}$ & 90 & 0.396 & 9.604 & 100 & 0.000396 \\
\hline
\end{tabular}

Samples were prepared and treated similarly to previous activities except for the inclusion of the resin before the addition of copper. Addition of the resin required additional working conditions such as the contact temperature and time, mode and extent of mixing and preincubation time. Samples were subjected to filtration at the end of the pre-incubation period to remove the phenol-resin complex and the residual resin.

In this trial, 10 and 20 milligrams (mg) of the PVPP resin were used. Grayish-white sediment/precipitate was formed during the preincubation period and no pinking occurred. After 5 hours of incubation the $10 \mathrm{mg}$ sample turned pink but no pinking was observed for the samples containing $20 \mathrm{mg}$ of the resin. Absorbance readings were noted to be higher for samples pre-incubated for 4 hours.

Another trial was conducted using increased amounts of the resin $(20,30$ and 40 $\mathrm{mg}$ ). The mode of mixing was through the use of a water-bath shaker to facilitate simultaneous and uniform treatment of the samples. Preincubation periods were set at 2, 4 and 6 hours. No pinking occurred during the pre-incubation duration but sediments were formed. All samples turned pink at hour 4 of the reaction period, including the respective controls (untreated with resin). This result implies that 
resin amounts of 20, 30 and $40 \mathrm{mg}$ were not sufficient to prevent pinking of the coconut water. Furthermore, no notable difference in absorbance readings was recorded for the 2, 4 and 6 hours of pre-incubation.

The amount of resin used was based on the recommended amounts for wines. According to the literature, wines contain many phenolic compounds and these amounts are sufficient to effect reduced color or prevent pinking of white wines. It must be supposed that during the preincubation period, where the enzyme is at its optimum temperature for activity, binding of the resin and the tyrosine did occur as evidenced by the "unpinking" of the coconut water. Upon filtration, enough of the substrate could have been left in the system to react with the enzyme. It is also possible that the resin was not well mixed. Since the effectiveness of the resin lies in many factors, aside from the amount added, the next trial focused upon the mode of mixing.

Three modes of mixing were tested - manual shaking, water bath shaking and magnetic stirring, and two mixing times - 30 and 60 minutes. Mixing was done at $28{ }^{\circ} \mathrm{C}$ and preincubated for 2 hours (previous runs showed no difference in duration of pre-incubation in terms of hindering the pinking) at $34{ }^{\circ} \mathrm{C}$. The amount of PVPP added was fixed at $20 \mathrm{mg}$ (on a cost consideration). Results showed that the modes of mixing employed and the mixing times were not significantly different. Samples and controls were all observed to pink with a noticeable a tinge of brown at hour 3 of the reaction period.

Another trial was made focusing on the length of mixing time and contact temperature. Three contact temperatures and mixing times were applied: 4,28 , and $34{ }^{\circ} \mathrm{C}$ and 30,60 , and 90 minutes respectively. The amount of PVPP was kept at $20 \mathrm{mg}$. The mode of mixing chosen was manual shaking, to facilitate simultaneous runs at the given contact temperatures. Data gathered showed least absorbance at $4^{0} \mathrm{C}$, although absorbance readings of the other test temperatures were not so different. Least absorbance was also observed on samples mixed for 30 minutes, however a graph of the reaction rate is quite erratic and does not show a plateau. Discoloration occurred at hour 4 of the reaction period.

\section{Calcium bentonite}

A 5\% slurry was prepared in advance. Dosage rates were followed as recommended for beers and wines. An amount of $5 \mathrm{ml}$ of the slurry was added to the coconut water. Mixing mode was that of manual shaking for a period of 60 minutes at $28{ }^{\circ} \mathrm{C}$. Pre-incubation was for 2 hours at $34{ }^{0} \mathrm{C}$. Treatment of coconut water with bentonite at the set amount was not enough to prevent the pinking which occurred at hour 3 of the reaction period.

\section{Gelatin}

A $6 \%$ slurry was prepared prior to the test trial and an amount of $5 \mathrm{ml}$ was added to coconut water. The same working conditions as for the treatment with bentonite were applied to the testing of gelatin. Pinking still occurred on treated samples.

A comparison of the three food-grade resins, bentonite, gelatin and PVPP (20mg), was made using the above procedures, prepared under the same working conditions. Bentonite showed the least absorbance at the end of the 6hour reaction period. However, all samples discolored at hour 3. Figure 17 below shows the percent absorbance of each food-grade resin.

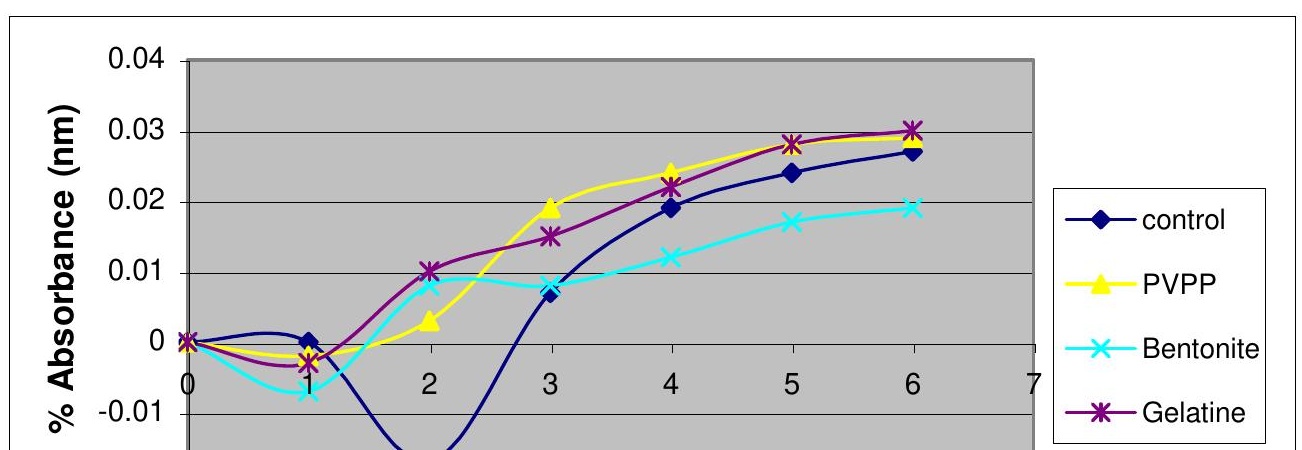


Figure 17. \% Absorbance of samples treated with different food-grade resins 14; Sfat,

1975; Dadic and Lavallee, 1983; McMurrough et al., 1992a, 1993; O'Reilly, 1994. As cited in McMurrough, I., D. Madigan and M.R. Smyth. 1995. Adsorption by Polyvinylpolypyrrolidone of Catechins and Proanthocyanidins from Beer. $J$. Agric. Food Chem. 43. 2687-2691.

Arroyo, P.T. 1982. The Science of Philippine Foods. $2^{\text {nd }}$ rev. ed. Abaniko Enterprises. Quezon City.

Banzon, J.A., O.N. Gonzalez, S.Y. de Leon and P.C. Sanchez. 1990. Coconut as Food. Philippine Coconut Research and Development Foundation, Inc. (PCRDF). Commonwealth Avenue, Diliman, Quezon City.

Banzon, J. A. and J.R. Velasco. 1990. Coconut Production and Utilization. Philippine Coconut Research and Development Foundation, Inc. (PCRDF). Ortigas, Pasig City.

Burnette, F.S. 1977. Peroxidase and its relationship to food flavor and quality: A review. J. Food Science, 42:1. As cited in Nicolas, J.J., F.C Richard-Forget, P.M. Goupy, MJ.A. Amiot and S.Y. Aubert. 1994. Enzymatic Browning Reactions in Apple and Apple Products. ASEAN Post Production Information Exchange. Critical Reviews in Food Science and Nutrition. v34 n2. p.109.

Charley, H. 1973. Food Science. Ronald Press Co. New York, New York.

Dziezak, J.D. 1991. Enzymes: Catalysts for Food Processes. Food Technology. 45 (1): 78-85.

Fennema, O.R. Ed. 1985. Food Chemistry. $2^{\text {nd }}$ ed. Marcel Dekker Inc. Madison Ave., New York, New York.

Francis, J.F. 2000. Wiley Encyclopedia of Food Science and Technology. $2^{\text {nd }}$ ed. v3. John Wiley and Sons, Inc. New York, New York.

Jones, D.E. 1965. Banana Tannin and its Reaction with Polyethylene Glycol. Nature. 206. 299-300. As cited in Silanikove, N., D. Shinder, N. Gilboa, M. Eyal and Z. Nitsan. 1996. Binding of Poly(ethylene glycol) to Samples of Forage Plants as an Assay of Tannins and Their Negative Effects on Ruminal Degradation. J. Agri.Chem. 44, 32303234.

Leelakul, S. 1978. Pink Discoloration in Canned Green Langka (Jackfruit). Unpublished Masters Thesis in Food Science and Technology. Department of Food Science and Nutrition, College of 
Home Economics, University of the Philippines. Diliman, Quezon City.

Lerch, K. and Ettlinger, L. 1972. As cited Whitaker, J.R. 1994. Polyphenol Oxidase. In: Wong, T.C. ed. 1995. Food Enzymes. Structure and Mechanism. DWS Chapman and Hall.

Makkar, H.P.S., M. Blummel and K. Becker. 1995. Formation of Complexes Between Polyvinylpyrrolidones or Polyethylene glycols and Tannins, and Their Implication in Gas Production and True Digestibility In Vitro Techniques. Br. J. Nutri. 73, 897913. As cited in Silanikove, N., et al. 1996.

Binding of Poly(ethylene glycol) to Samples of Forage Plants as an Assay of Tannins and Their Negative Effects on Ruminal Degradation. J. Agri. Chem. 44, 3230-3234.

Metzler, D.E. 1977. Biochemistry. The Chemical Reactions of Living Cells. Academic Press Inc., New York, New York.

Mortimer, C.E. 1986. Chemistry. $6^{\text {th }}$ Ed. Wadsworth Inc. Belmont, California.

Nicolas, J.J., F.C Richard-Forget, P.M. Goupy, MJ.A. Amiot and S.Y. Aubert. 1994. Enzymatic Browning Reactions in Apple and Apple Products. ASEAN Post Production Information Exchange (APEX). Critical Reviews in Food Science and Nutrition. v34 n2. p.109.

Olah, A.F. and W.C. Mueller. 1981. Ultrastructural Localization of Oxidative and Peroxidative Activities in a Carrot Suspension Cell Structure. Protoplasmia 106. 231-248. As cited in Whitaker, J.R. Polyphenol Oxidase. In: Wong, T.C. ed. 1995. Food Enzymes. Structure and Mechanism. DWS Chapman and Hall.

O'Reilly. 1993. As mentioned in Zoecklein, B.W., K.C. Fugelsang, B.H. Gump and F.S. Nury. 1995. Wine Analysis and
Production. Chapman and Hall. New York, New York.

Osuga, D., A. Van Der Schaaf and J.R. Whitaker. 1994. Control of Polyphenol Oxidase Activity Using a Catalytic Mechanism. In: Yada, R.Y., R.L. Jackman and J.L. Smith ed. Protein Structure-Function Relationships in Foods. Blackie Academic \& Professional, Glasgow, Scotland. pp. 62-88. As cited in Wong, T.C. ed. 1995. Food Enzymes. Structure and Mechanism. DWS Chapman and Hall.

Padiernos, R.E. 1980. Enzymatic Browning of Coconut Pith. Unpublished Masters Thesis in Food Science and Technology. Department of Food Science and Nutrition, College of Home Economics, University of the Philippines. Diliman, Quezon City.

Paguirigan, F., M. Molina, L. Lorenzana, N. Valencia and D.Masa. 2000. Buko Drink: Enhancing Its Quality and Marketability. Selected Topics on Current Trends and Prospects in Enhancing the Coconut Industry. Coconut Week 2000 Symposium Proceedings. Magat, S. and D. Masa. Ed. Philippine Coconut Authority (PCA). Diliman, Quezon City.

Pamintuan, E.R. 2002. Storage Stability of Pasteurized Buko Juice in PET Bottles. Unpublished Undergarduate Thesis in Food Science and Technology. Department of Food Science and Nutrition, College of Home Economics, University of the Philippines. Diliman, Quezon City.

Pandalai, K.M. and K.P.V. Menon. 1958. The Coconut Palm. A Monograph. Indian Central Coconut Committee. Ernakulam, S.India.

Philippine Coconut Authority. 1990. Coconut: Towards a Healthful Living. Market Research \& Promotions Division, Market 
Development Department. Philippine Coconut Authority (PCA). Diliman, Quezon City.

Philippine Coconut Authority 1979. Technical Data Handbook on the Coconut. Its Products and By-Products. Research Coordination and Documentation Center, Corporate Planning and Information Office. Philippine Coconut Authority (PCA). Diliman, Quezon City, Philippines.

Polyclar ${ }^{\circledR}$ BV Brochure. Functional Drink, Tea and Juice Stabilizers, Clarifiers and Texturizers. International Specialty Products (ISP). Surrey, U.K.

Pradera, E.S., E. Fernandez and O. Calderon. 1942. Coconut Water - A Clinical and Experimental Study. Am. J. of the Dis. of Children. 64:977. As cited in Philippine Coconut Authority 1979. Technical Data Handbook on the Coconut. Its Products and By-Products. Research Coordination and Documentation Center, Corporate Planning and Information Office. Philippine Coconut Authority (PCA). Diliman, Quezon City.

Shahidi, F. and M. Naczk, 1995. Food Phenolics. Sources, Chemistry, Effects and Applications. Technomic Publication. Lancaster, Penn. U.S.A.
Sison, Bienvenido, Jr. C. 1984. Coconut Water (Its Properties and Uses). Coconuts Today. April 27, 1984.

Solomon, E.I., M.J. Baldwin and M.D. Lowery. 1992. Electronic Structures of Active Sites in Copper Proteins: Contributions to Reactivity. Chem. Rev. 92, 521-542. As cited in Wong, T.C. ed. 1995. Food Enzymes. Structure and Mechanism. DWS Chapman and Hall.

Whitaker, J.R. 1994. Polyphenol Oxidase. In: Wong, T.C. ed. 1995. Food Enzymes. Structure and Mechanism. DWS Chapman and Hall.

Wong, T.C. ed. 1995. Food Enzymes. Structure and Mechanism. Chapman and Hall.

Zoecklein, B.W., K.C. Fugelsang, B.H. Gump and F.S. Nury. 1995. Wine Analysis and Production. Chapman and Hall. New York, New York. 